Collection: 3rd International Elm Conference, Florence (Italy - 2013)

"The elms after 100 years of Dutch Elm disease"

Guest Editors: A. Santini, L. Ghelardini, E. Collin, A. Solla, J. Brunet, M. Faccoli, A. Scala, S. De Vries, J. Buiteveld

\section{Comparison of commercial elm cultivars and promising unreleased Dutch clones for resistance to Ophiostoma novo-ulmi}

\author{
Joukje Buiteveld ${ }^{(1)}$, Bert Van Der Werf ${ }^{(1)}$, Jelle A Hiemstra ${ }^{(2)}$
}

In the past centuries elms (especially Ulmus $\times$ hollandica) have been dominant and largely appreciated trees in cities and rural landscape in the Netherlands. As a result of two Dutch Elm Disease (DED) epidemics in the $20^{\text {th }}$ century these trees largely disappeared from the landscape. Despite the introduction of new cultivars with enhanced DED-resistance, by the end of the $20^{\text {th }}$ century the elm had disappeared from the top 20 list of trees produced by Dutch nurseries. New cultivars with increased resistance to DED are used to a limited extent only, due to a lack of confidence in their resistance among urban foresters and landscape managers. This paper reports on a study aimed at restoring the position of elm as a street tree in the Netherlands by providing information on resistance of the currently available cultivars to Ophiostoma novo-ulmi causing DED. All elm cultivars currently on the Dutch market were compared in an inoculation test. In 2007 a field experiment including 18 cultivars, one species and 10 non-released clones from the Dutch elm breeding program was established. Two cultivars were used as reference clones: "Commelin" (relatively susceptible) and "Lobel" (relatively resistant). In 2008 and 2009 the elms were stem-inoculated with 0 . novo-ulmi and disease development was assessed throughout the summer and the following year. Clear differences among cultivars in the resistance to $O$. novo-ulmi were found, with "Columella", "Sapporo Autumn Gold"' and "Rebella" being highly resistant and significantly different from "Lobel" and "Regal", "Urban", "Belgica", "Den Haag", and the $U$. laevis seedlings being the most susceptible and comparable to "Commelin". The non-released clones performed similarly to "Lobel"'or even better. The ranking of cultivars based on their level of resistance to 0 . novo-ulmi in the field test corresponds well with previous experiences from urban green practices. Our conclusion is that a wide range of cultivars with a good to excellent level of resistance are currently available, with a broad genetic base due to different parentage and the use of exotic germplasm in the crossings. Such broad genetic background may contribute to the stability of resistance in the case new forms of the disease appear. The non-released clones performed well as compared to the released cultivars, thus giving good opportunities to further broaden the current range of cultivars on the Dutch and European markets.

Keywords: DED-resistance, Elm Cultivars, Ulmus, Inoculation Test, Ophiostoma Novo-ulmi

\section{Introduction \\ In the past centuries elms (Ulmus spp.) be- came a very important part of the landscape in large areas of the Netherlands. Elms have a combination of highly valued characteri- stics such as no specific requirements con- cerning soil type, the ability to resist (sea) winds, the very good recovery from mecha- nical damage, its adaptability to city condi- tions including its ability to endure de-icing salts and closed pavements and its much ap-}

$\square$ (1) Alterra, Wageningen UR, P.O. box 47 , 6700AA Wageningen (The Netherlands); (2) Applied Plant Research, Wageningen UR, P.O. Box 85, $2160 \mathrm{AB}$ Lisse (The Netherlands)

@ Joukje Buiteveld (joukje.buiteveld@wur.nl)

Received: Dec 20, 2013 - Accepted: May 18, 2014

Citation: Buiteveld J, Van Der Werf B, Hiemstra JA, 2015. Comparison of commercial elm cultivars and promising unreleased Dutch clones for resistance to Ophiostoma novo-ulmi. iforest 8: 158-164 [online 2014-08-07] URL: http://www. sisef.it/iforest/contents/?id=ifor1209-008

Communicated by: Alberto Santini

(Hiemstra et al. 2006). Since 1928, elm breeding for resistance to DED has resulted in the release of several more or less resistant cultivars to the European market. Especially in the Netherlands - where the first cultivar ("C. Buisman") was released in 1936 - and the USA, large and long-term selection programs have been performed resulting in a number of hybrid clones with moderate to very good resistance. Also, more recently, other European programs on elm breeding were set up, e.g., in Italy, Spain and France (Mittempergher \& Santini 2004). Today a wide range of clones of different DED-resistance and different parentage is available on the market. However, the use of these new elm cultivars in the Netherlands is still limited. "Vegeta" and "Commelin" elms that were planted in very large numbers in the second part of the twentieth century because of their level of resistance to DED caused by O. ulmi were attacked by $O$. novo-ulmi. Apparently, the lasting problems with DED in these earlier released cultivars, such as the sanitation costs for removing and replacing diseased and dead trees, has led to a lack of confidence in the resistance of newly released cultivars among urban foresters and landscape managers. As a result and despite its glorious past, around the year 2000 the elm was not even listed in the top 20 of street trees produced by Dutch tree nurseries (Geurts \& Hiemstra 2002). However, the outcome of a survey among Dutch trees nurseries was that there is no other species that can replace the elm and it was concluded that confidence in the elm should be restored. None of the substitute tree species has the same set of characteristics that makes the elm so well-suited as a street tree; therefore the best replacement for the classical Dutch elm is still an elm, provided it is resistant to DED (Hiemstra et al. 2006). This paper reports on a study aimed at restoring the posi- 
Tab. 1 - Cultivars and clones included in the trial and their parentage. $(*)$ : According to Heybroek et al. (2009) and references herein: $5=$ very good; 4 =good, $3=$ moderate, $2=$ low, $1=$ minimal, n.a. $=$ not available. $(* *)$ : Good field resistance due to unattractiveness to the DED vector (Scolytus).

\begin{tabular}{|c|c|c|c|c|}
\hline $\begin{array}{l}\text { Clone/ } \\
\text { Species }\end{array}$ & Origin & Provenance or parentage & $\begin{array}{c}\text { Year } \\
\text { released }\end{array}$ & $\begin{array}{l}\text { Resistance } \\
\text { to DED* }\end{array}$ \\
\hline Commelin & NL & U. $x$ hollandica "Vegeta" $\mathrm{x} U$. minor & 1960 & 2 \\
\hline Groeneveld & NL & U. glabra (no. 49) x U. minor no. 1 & 1963 & 3 \\
\hline Lobel & NL & $\begin{array}{l}\text { (U. wallichiana } \mathrm{x} \text { U. glabra "Exoniensis") } \\
\text { x "Bea Schwartz" selfed) }\end{array}$ & 1973 & 4 \\
\hline Dodoens & NL & $\begin{array}{l}\text { (U. glabra "Exoniensis" x U. wallichiana) } \\
\text { selfed }\end{array}$ & 1973 & 4 \\
\hline Plantijn & NL & $\begin{array}{l}\text { (U. glabra "Exoniensis" x U. wallichiana) } \\
\text { x U. minor }\end{array}$ & 1973 & 4 \\
\hline Clusius & NL & $\begin{array}{l}\text { (U. glabra "Exoniensis" x U. wallichiana) } \\
\text { x "Bea Schwartz" selfed }\end{array}$ & 1983 & 4 \\
\hline Columella & NL & Plantijn selfed? & 1989 & 5 \\
\hline 1028 & NL & $\begin{array}{l}((U . \text { wallichiana } \times \text { U. minor }) \times(U . \text { pumila } \\
\mathrm{x} U . \text { minor })) \times \text { Plantijn }\end{array}$ & - & n.a. \\
\hline 1043 & NL & U. davidiana var. japonica selection & - & n.a. \\
\hline 1111 & NL & Plantijn x Dodoens & - & n.a. \\
\hline 1236 & NL & Plantijn x Wredei & - & n.a. \\
\hline 1241 & NL & $\begin{array}{l}\text { Lobel } \times((U . \text { pumila } \times U . \text { davidiana } \text { var. } \\
\text { japonica }) \times \text { U. pumila }))\end{array}$ & - & n.a. \\
\hline 1304 & NL & (U. glabra x U. minor) $\times$ Commelin & - & n.a. \\
\hline 1312 & NL & $((U$. pumila $x$ U. minor $) \times$ Commelin) $)$ OP & - & n.a. \\
\hline 1315 & NL & $\begin{array}{l}((U . \text { wallichiana } \times \text { Commelin }) \times(\text { Dodoens } \\
\mathrm{x}(U . \text { glabra } \times \text { U. minor }))\end{array}$ & - & n.a. \\
\hline 1322 & NL & $\begin{array}{l}\text { U. minor } \mathrm{x}(U . \text { pumila } \mathrm{x} U . \text { minor }) \\
\mathrm{x} U . \text { minor }\end{array}$ & - & n.a. \\
\hline 1324 & NL & $\begin{array}{l}\text { (U. wallichiana } \times \text { Commelin }) \times \text { Dodoens } \\
\mathrm{x}(\text { U. glabra } \mathrm{x} \text { U. minor })\end{array}$ & - & n.a. \\
\hline Belgica & B & U. $x$ hollandica & - & 1 \\
\hline Den Haag & NL & U. pumila $\mathrm{x}$ "Belgica" & 1936 & 3 \\
\hline Cathedral & US & U. pumila $\mathrm{x} U$. davidiana var. japonica & 1994 & $4-5$ \\
\hline New Horizon & US & U. davidiana var. japonica $\times$ U. pumila & 1995 & 5 \\
\hline Regal & US & $\begin{array}{l}\text { Commelin } \times(U . \text { pumila } \times \text { U. minor Hoer- } \\
\text { sholmiensis) }\end{array}$ & 1983 & 4 \\
\hline Rebona & US & U. davidiana var. japonica $\times$ U. pumila & 1994 & 5 \\
\hline Rebella & US & U. america $\times$ U. parvifolia & 2011 & n.a. \\
\hline $\begin{array}{l}\text { Sapporo Au- } \\
\text { tumn Gold }\end{array}$ & US & U. pumila $\mathrm{x} U$. davidiana var. japonica & 1975 & 4 \\
\hline Homestead & US & $\begin{array}{l}\text { U. pumila } \mathrm{x}((\text { Commelin }) \times(U \text {. pumila } \\
\mathrm{x} \text { "Hoersholmiensis")) }\end{array}$ & 1984 & $4-5$ \\
\hline Pioneer & US & U. $x$ hollandica selection & 1984 & 4 \\
\hline Urban & US & $\begin{array}{l}\text { (U.x hollandica "Vegeta" x U. minor) } \\
\mathrm{x} U \text {. pumila }\end{array}$ & 1976 & 3 \\
\hline U. laevis & NL & The Netherlands & - & $* *$ \\
\hline
\end{tabular}

tion of the elm as a street tree in the Netherlands by providing information on the level of DED-resistance of the currently available elm cultivars. The objective was to compare in one inoculation test all cultivars released from the Dutch breeding program and from foreign breeding programs available in the Dutch tree nursery market. From the Dutch elm breeding program which was put on hold in 1992, six cultivars issued between 1963 and 1989 with moderate to very high resistance, were included (Heybroek 1993). The USA breeding programs also have resulted in new cultivars (Mittempergher \& Santini 2004, Smalley \& Guries 1993), with se- veral of them being used in the Netherlands lately in landscape and urban forestry. At the start of the study in 2005 eight cultivars from the USA were available in the Netherlands, which were all included in the study, together with an unnamed clone being considered for release. These are believed to have a high resistance based on tests in the USA, but have never been tested under Dutch conditions or compared to such a large number of Dutch cultivars in one test. More recently, several new cultivars with good resistance were issued in Italy (Santini et al. 2002, 2007, 2012) and Spain (Martin et al. 2014). However, in 2005 these cultivars were not yet available on the Dutch market and subsequently not included. In 2002 and 2006, INRA (France) released the cultivars "Wanoux" and "Nanguen" (Pinon et al. 1998, Pinon 2007). Both originate from the Dutch breeding program, but were not released due to the fact that they were thought to be of less interest for the Netherlands based on results from previous adaptability trials. As a consequence they were not available in Dutch tree nurseries in 2005 and therefore not included in the test. Additionally, 10 unreleased selections from the Dutch breeding program were compared with the available cultivars in order to investigate whether these clones have an increased resistance compared to the currently available cultivars.

\section{Material and Methods}

Plant material and experimental design

The field test comprised of 18 cultivars, one species and 10 new unreleased selections from the Dutch breeding program (Alterra, formerly known as the Dorschkamp Institute). Cultivars included were all those with moderate to high DED-resistance and available in 2005 in the Dutch tree nursery market. These included nine hybrid cultivars developed in the USA, but not yet tested under Dutch conditions and six hybrid cultivars from the Dutch breeding program. Additionally, the historical elm cultivar "Den Haag" was included, as it is highly appreciated by some city foresters in the Netherlands because of good field performance, and U. lae$v i s$ as it is rather popular in the Netherlands. It has some form of field resistance due to its unattractiveness to the beetle, which acts as a vector for the fungus. For reasons of comparison, the old historical non-resistant cultivar "Belgica" was also added. Finally, 10 new and not yet released selections, mainly complex hybrids from the Dutch breeding program (Heybroek 1993) and currently tested in adaptability tests by Alterra were included in the trial. The two Dutch hybrid clones "Lobel" and "Commelin", with known DED response from earlier inoculations tests performed by Heybroek (1993) were added as reference clones for respectively good and low disease resistance. The selected cultivars and clones and their parentage are shown in Tab. 1. The plants were propagated by soft cuttings (USA cultivars, as these cultivars are always sold as own-rooted plants) or graftings on an U. glabra rootstock (all other cultivars and the new Alterra selections) in 2006. For the species U. laevis seedlings were used. In April 2007 these plants were planted in a field trial at a tree nursery in Ommeren, the Netherlands $\left(51^{\circ} 56^{\prime} \mathrm{N}, 5^{\circ}\right.$ $29^{\prime}$ E) on a clay soil (river deposit) at a spacing of $1 \mathrm{~m}$ within and $1.35 \mathrm{~m}$ between rows. The plants were planted in a randomized block design with nine blocks and 
four ramets of each clone per block. After planting the plants were watered several times, nevertheless the very dry weather conditions in the spring of 2007 resulted in a substantial loss of plants in the first season. These plants were replaced by spare plants from another part of the field in April 2008 The soil was kept free from weeds by using a herbicide until the canopy closed. No regular pruning was done, only some low branches were removed to enable better access to the field and when needed to maintain stability of the trees. Finally, at the start of the experiment 976 plants in total were available for inoculation.

\section{Inoculations}

Four independent inoculations with Ophiostoma novo-ulmi were performed on different replicates of the same plant material, thus each tree was inoculated once. In both 2008 and 2009 two inoculations were carried out, the first in June and the second in July, coinciding with the period in which elms in the Netherlands are at their greatest susceptibility to the fungus. For each inoculation, 9 plants per clone were used (one in each block). Inoculations were performed with an aggressive well-known tester isolate $\mathrm{H} 328$ belonging to the subspecies $O$. novo-ulmi ssp. novo-ulmi, formerly known as the EAN race (kindly provided by C. M. Brasier, Forestry Commission, UK). The conidial suspension was prepared according to the method by Tchernoff (1965), modified according to Sutherland et al. (1995). The inoculum consisted of a conidial suspension of $O$. novo-ulmi $\left(10^{6}\right.$ spores $\left.\mathrm{ml}^{-1}\right)$. Inoculations were performed using the Dutch inoculation method (Heybroek 1993), by forcing a knife with a drop of $0.12 \mathrm{ml}$ inoculum on it into the vascular xylem of the lower stem at 30$50 \mathrm{~cm}$ height. This severe method ensures that even clones with reasonable resistance may develop some disease symptoms and that maximum differentiation in resistance level between clones can be obtained. Inoculations were performed in the morning only on dry and sunny days to be sure that the inoculum was absorbed by the trees very easily. Knowing that symptoms are influenced by the vigor of the clone and ramet (Santini et al. 2005), care was taken to inoculate well established and vigorously growing plants only. Trees with low vigor (shorter $<1 \mathrm{~m}$ ) or incomplete bud burst were excluded from inoculation and dropped from the experiment. Also replacement trees, planted in 2008, were not inoculated in 2008 but left for inoculation in 2009. The average stem diameter of the clones measured at $1 \mathrm{~m}$ height in April 2008 prior to inoculation varied from $4.5 \mathrm{~cm}$ to $17.5 \mathrm{~cm}$. Eventually, 116 of the 976 plants available in Spring 2008 were not inoculated, because they died during the experiment prior to inoculation or showed low vigor (shorter $<1 \mathrm{~m}$ ). During the first inoculation, a number of spare plants at another part of the field were inoculated with water.

\section{Assessments}

Typical symptoms for Dutch elm disease are wilting, yellowing of the leaves, leaf fall, formation of "shepherd's crooks" and dieback of twigs. To evaluate symptom development in the trees, the percentage of defoliation 4 and 8 weeks after inoculation, disease index 4 and 8 weeks after inoculation, and recovery ability of trees one year after inoculation were assessed. The disease index was based on a scale with 9 infection classes, expressing the extent of wilting and twig dieback in the tree. Classes were defined as follows: $0=$ no symptoms; $0.5=$ start of leaf necrosis; 1 = yellowing and/or wilting of leaves, but no dieback of twigs; $1.5=$ severe leaf fall and/or dieback of the tips of the twigs or inner twigs of the crown; 2 = partly or completely dieback of young top twigs with or without formation of "shephard's crooks"; $2.5=$ dieback to the base of this year's shoots and/or massive occurrence of diseased twigs; 3 = dieback of 1-year old shoots as well as partly two-year-old shoots (up to halfway); $3.5=$ dieback of 1-year old shoots as well as older shoots; $4=$ severe dieback (more than half of the tree is dead). During the next growing season following inoculation of trees, the ability to recover was assessed based on the percentage of defoliation of the restored foliage and proportion of crown mortality. Mortality in the crown was assessed using 5 classes: $0=$ healthy, no crown dieback; $1=$ dieback in $<$ $25 \%$ of the crown; $2=25-50 \% ; 3=51$ $75 \%$; and $4 \geq 75 \%$ of the crown shows dieback.

As symptoms in the more susceptible clones usually increase with time, symptoms were also recorded 12 weeks after the first inoculation. In the following three inoculations, defoliation and disease index were only assessed 4 and 8 weeks after inoculations.

\section{Data analysis}

The disease index, defoliation ( $\%$, rounded to nearest decimal) and crown mortality observations are ordinal variables and to test differences between clones would normally be analyzed with a Chi square test or generalized (log) linear or ordinal-logistic model (GLM). However, the counts in some combinations (e.g., clone $\mathrm{x}$ disease index class) were very low or even zero, which hamper such analysis. Additionally, our interest lies in the ranking and grouping of the clones based on their level of resistance. Therefore, in order to analyze the ranking and grouping of the clones according to their performance for defoliation, disease index and crown mortality a Monte-Carlo randomization test was used (Manly 2007). A $\chi^{2}$ statistic was calculated $\left(\chi_{\text {observed }}^{2}\right)$ on the basis of observed data in a two-way table, obtaining an estimated probability for each class. Using the clone totals for each and the calculated probabilities, simulated frequencies were calculated. For each test this was done 10000 times to get an simulated distribution of $\chi^{2}$. If

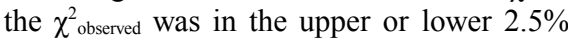
tail then significance was inferred $(\mathrm{p}<0.05$, two-tailed). In order to rank the clones they were classified according to their average score for disease index, defoliation or crown mortality. To make groupings, inclusion or exclusion of only adjacent individuals were considered. Using the above tests, maximum sized groups of clones containing no significant differences between the clones within that group were obtained. All symptom assessments were performed by two independent observers. For the statistical analysis only the maximum (index, percentage) value was used (bias to classify clones to be more susceptible). Initially, the analysis was carried out separately for each inoculation. However, in the third inoculation (performed in June 2009), the two control cultivars "Lobel" and "Commelin" with known levels of resistance which were included in the trial to investigate whether the four inoculations were successful, showed substantially less symptoms than expected. Subsequently, it was concluded that the third inoculation was not successful and the analysis was performed excluding this inoculation (a total of 668 plants). Additionally, Spearman's rank correlation coefficient was calculated for the different parameters considered (percentage of defoliation, disease index, crown dieback and diameter of the plants).

\section{Results}

\section{Methodological aspects}

Symptoms developed only in inoculated trees, while none of the untreated control trees (inoculated with water) showed disease symptoms. One of the four independent inoculations performed (2 June 2009) was not successful, resulting in substantially less symptom development in both "Lobel" and "Commelin" reference cultivars as compared to the other tree inoculations (Fig. 1). Furthermore, their symptom development was less than expected based on results from previous inoculation tests performed in the Dutch breeding program (disease index range over the past 5 inoculation tests: "Lobel" d.i. $=1.3-3.0$ and "Commelin" d.i. = 2.2-3.3, unpublished results). The limited symptom development after the third inoculation may be likely due to the conidial suspension used, whose concentration was considerably lower than in the other three inoculations $\left(8 \cdot 10^{4}\right.$ con. $\mathrm{ml}^{-1}$ instead of $1 \cdot 10^{6}$ con. 


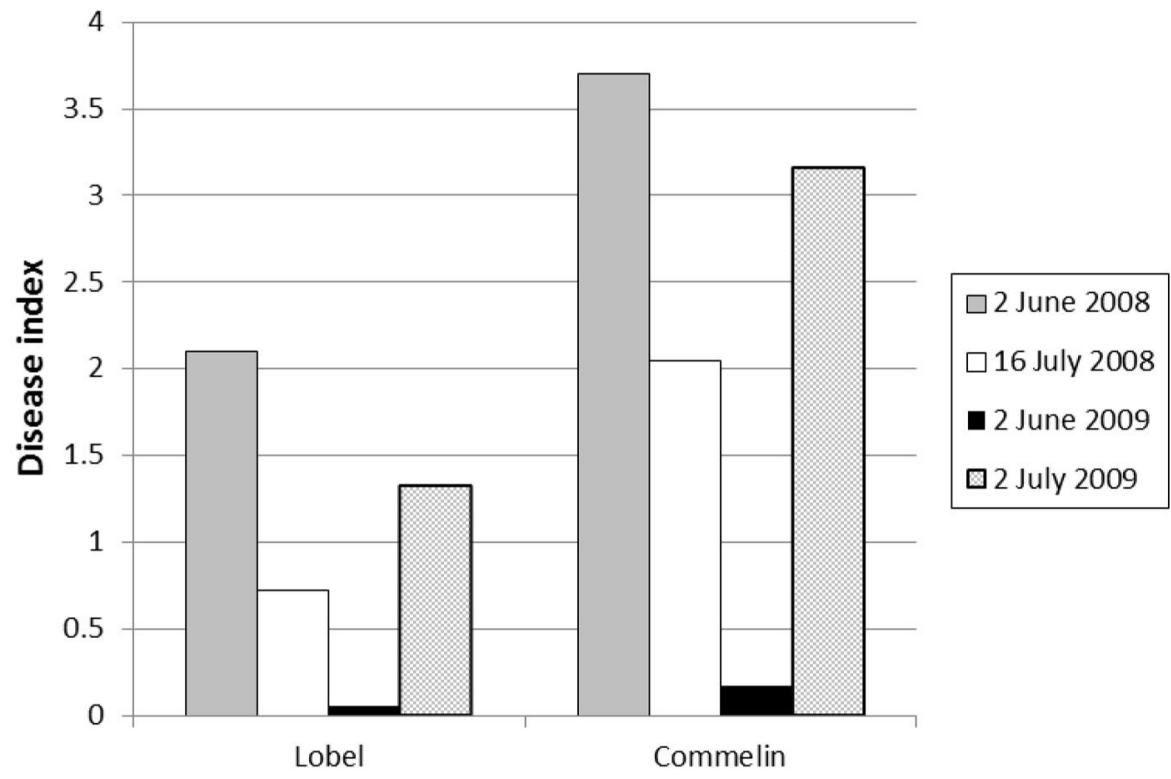

Fig. 1 - Differences in symptom expression (disease index after 8 weeks) between the four inoculation dates for the two control clones "Lobel" and "Commelin". $\mathrm{ml}^{-1}$ ). Because of the limited symptom development, data of this third inoculation were discarded from further analyses.

When comparing the three dates of symptom assessment, first symptoms were visible in most clones 4 weeks after inoculations, which further developed in some of these clones. Differences in symptom expression between the clones were very clear 8 weeks after inoculations (Fig. 2a, Fig. 2b). Since symptoms were rather constant 8 weeks after inoculation and the assessment date corresponded with evaluation dates reported by other studies (Santini et al. 2005, Pinon et al. 2005 , Solla et al. 2005), it was decided to assess symptoms after 4 and 8 weeks in the subsequent inoculations.

\section{Differences in DED symptom expression between clones}

\section{Defoliation and disease index}

Clear differences in the percentages of defoliation were already visible among clones 4 weeks after inoculation (Tab. 2). "Colu-
Fig. 2 - Disease index (A) and defoliation (B) assessed 4,8 and 12 weeks after inoculation (2 June 2008)
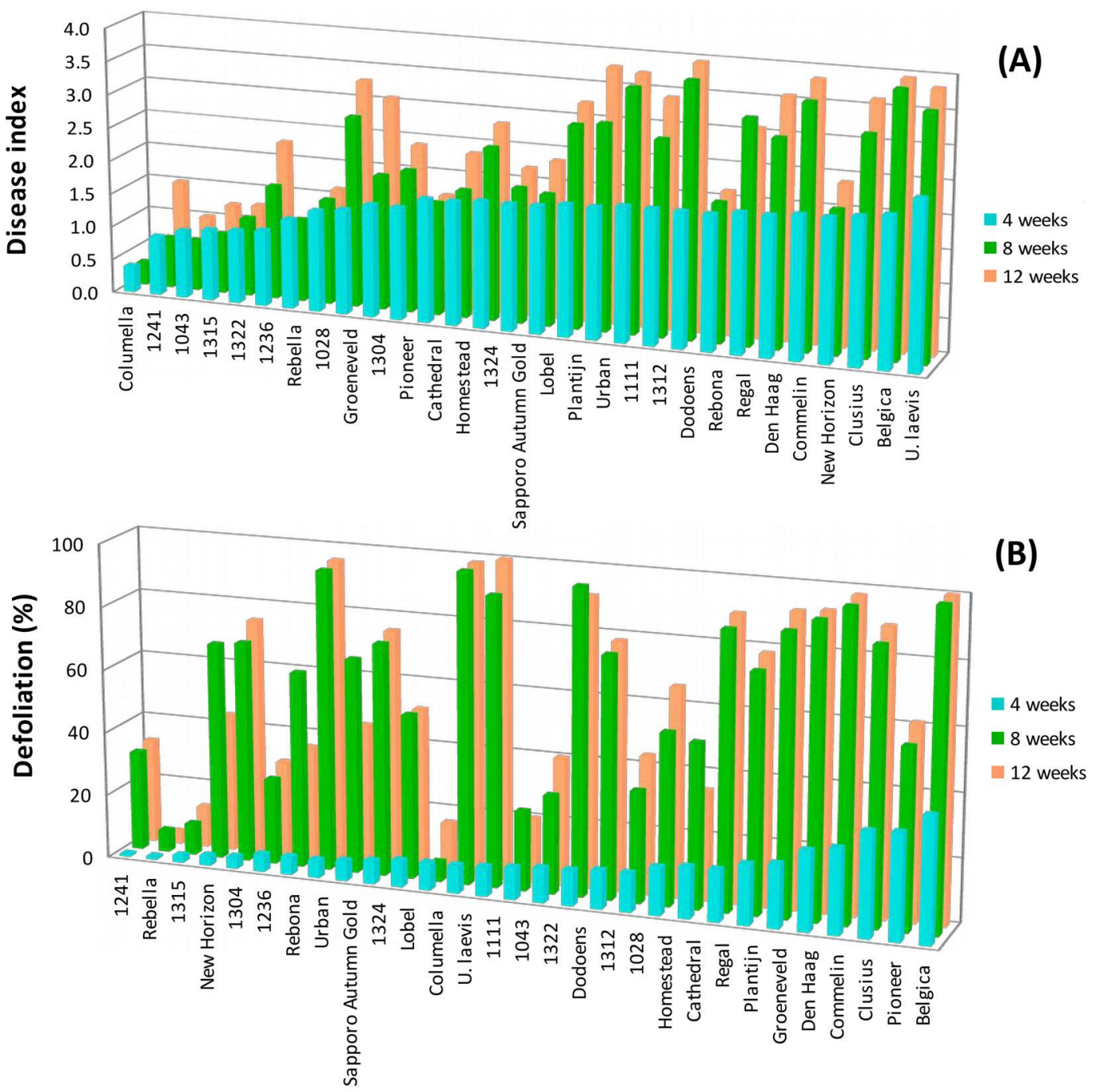
Tab. 2 - Average percentage of defoliation of the clones tested 4 weeks, 8 weeks and one year after inoculation (average of 3 inoculations). Values with the same letter do not differ significantly $(\mathrm{p}<0.05)$.

\begin{tabular}{|c|c|c|c|c|c|c|c|c|c|c|}
\hline \multirow{3}{*}{ Clone } & \multirow{3}{*}{$\begin{array}{c}\text { \# of } \\
\text { plants }\end{array}$} & \multicolumn{9}{|c|}{ Defoliation } \\
\hline & & \multicolumn{3}{|c|}{ after 4 weeks } & \multicolumn{3}{|c|}{ after 8 weeks } & \multicolumn{3}{|c|}{ after 1 year } \\
\hline & & $\%$ & Sign. & Rank & $\%$ & Sign. & Rank & $\%$ & Sign. & Rank \\
\hline 1241 & 8 & 0 & $\mathrm{a}$ & 1 & 17.5 & $a b$ & 4 & 16.3 & abcd & 5 \\
\hline 1315 & 26 & 2.7 & $\mathrm{a}$ & 2 & 5 & $a b$ & 2 & 5 & $\mathrm{a}$ & 1 \\
\hline 1304 & 27 & 4.4 & $a b$ & 3 & 26.7 & $a b$ & 9 & 24.8 & de & 13 \\
\hline Columella & 26 & 5.8 & $a b c$ & 4 & 4.6 & $\mathrm{a}$ & 1 & 5.4 & $a b$ & 2 \\
\hline 1322 & 15 & 6 & $a b c$ & 5 & 20 & $a b$ & 7 & 22.7 & bcd & 11 \\
\hline 1043 & 3 & 6.7 & $a b c$ & 6 & 16.7 & $a b$ & 3 & 13.3 & abcd & 4 \\
\hline 1111 & 27 & 8.1 & $a b c$ & 7 & 41.1 & $\mathrm{c}$ & 14 & 44.4 & efgh & 17 \\
\hline 1028 & 22 & 8.2 & $a b c$ & 8 & 19.5 & $a b$ & 6 & 19.1 & abcd & 7 \\
\hline Sapporo Autumn Gold & 22 & 8.6 & $a b c$ & 9 & 29.1 & $a b$ & 10 & 18.2 & abcd & 6 \\
\hline 1236 & 20 & 9 & abcd & 10 & 23.5 & $a b$ & 8 & 19.5 & abcd & 8 \\
\hline 1324 & 20 & 10.5 & abcd & 11 & 40 & $\mathrm{bc}$ & 13 & 37 & ef & 15 \\
\hline Lobel & 24 & 10.8 & abcd & 12 & 32.9 & $a b$ & 11 & 35.4 & def & 14 \\
\hline New Horizon & 27 & 14.8 & abcd & 13 & 35.9 & $\mathrm{~b}$ & 12 & 21.1 & abcd & 9 \\
\hline Plantijn & 28 & 15.7 & abcd & 14 & 45.4 & defg & 19 & 51.1 & efghij & 21 \\
\hline Homestead & 24 & 15.8 & abcde & 15 & 42.5 & d & 16 & 46.7 & efghi & 18 \\
\hline Dodoens & 27 & 16.7 & abcde & 16 & 55.2 & fgh & 22 & 55.9 & efghij & 22 \\
\hline Clusius & 24 & 18.3 & abcde & 17 & 46.7 & efgh & 21 & 48.3 & efghi & 19 \\
\hline 1312 & 14 & 19.3 & abcde & 18 & 46.4 & defgh & 20 & 49.3 & efghi & 20 \\
\hline Rebona & 24 & 20.8 & abcde & 19 & 44.6 & de & 17 & 21.3 & bcd & 10 \\
\hline Rebella & 27 & 21.1 & bcde & 20 & 18.9 & $a b$ & 5 & 5.6 & $a b c$ & 3 \\
\hline Cathedral & 24 & 29.6 & cdef & 21 & 41.3 & $\mathrm{~d}$ & 15 & 22.9 & $\mathrm{~cd}$ & 12 \\
\hline Pioneer & 26 & 30.8 & cdef & 22 & 44.6 & def & 18 & 43.1 & efg & 16 \\
\hline Groeneveld & 27 & 31.1 & cdef & 23 & 61.9 & fghi & 23 & 60.7 & efghij & 23 \\
\hline Regal & 24 & 32.9 & def & 24 & 72.9 & fghij & 24 & 72.5 & fghij & 25 \\
\hline Urban & 27 & 33.3 & ef & 25 & 73.7 & ghij & 25 & 71.9 & fghij & 24 \\
\hline U. laevis & 26 & 36.2 & ef & 26 & 90.8 & $\mathrm{j}$ & 29 & 90.8 & $\mathrm{j}$ & 29 \\
\hline Commelin & 27 & 43.7 & $\mathrm{fg}$ & 27 & 84.4 & $\mathrm{ij}$ & 27 & 84.8 & hij & 27 \\
\hline Den Haag & 26 & 49.6 & fg & 28 & 83.1 & hij & 26 & 82.3 & ghij & 26 \\
\hline Belgica & 26 & 60.4 & $\mathrm{~g}$ & 29 & 88.8 & $\mathrm{j}$ & 28 & 88.8 & ij & 28 \\
\hline
\end{tabular}

mella", "Sapporo Autumn Gold" and most of the Dutch unreleased clones showed less than $10 \%$ leaf fall, while the susceptible old cultivar "Belgica" already showed more than $50 \%$ leaf fall. Such differences became more pronounced after 8 weeks (Tab. 2). "Columella" and the Alterra clone 1315 still showed hardly any leaf fall, while leaf fall in the susceptible clones, such as "Belgica", "Commelin" and the $U$. laevis seedlings, became very severe with percentages up to 90 . Changes in ranking after 8 weeks were limited, except for "Rebella" that did not show increased defoliation after 8 weeks, and moved 15 places upward in the ranking. Comparison of the disease index (combined rating of wilting and twig dieback) after 4 and 8 weeks (see Tab. S1 in Appendix 1) also showed that in most clones symptoms progressed with time. After 8 weeks pronounced differences among clones in disease index were visible, ranging from clones with almost no or very limited symptoms to clones with severe symptoms. The resistant cultivar "Columella" and several Alterra clones (“1241”, “1322”, “1315”, “1043”, “1304”, "1028"), which hardly showed any symptoms or only wilting and leaf necrosis after 4 weeks, still were hardly diseased after 8 weeks (disease index $<1$ ). As expected, very susceptible clones such as "Belgica" and "Commelin" and the U. laevis seedlings showed severe symptoms after 8 weeks (disease index $>2.5$ ). Again, differences in clone ranking after 4 and 8 weeks were limited, except for a few clones. "Rebella", "New Horizon", "Cathedral" and "Rebona" did not show any substantial increase in disease index score and rose in ranking after 8 weeks, while "Dodoens", "1111" and "1312" descended in ranking.

\section{Recovery}

Assessment of defoliation in the next year (including branches with no leaves because of death of shoots) showed that most clones had a similar percentage of affected (defoliated and dead) shoots, as in the first year after 8 weeks. Most clones with clear symptoms in the season of inoculation were not able to form new foliage in the next season. Clones hardly showing any leaf fall in the year of inoculation, neither did show symptoms in the subsequent year. In a few American clones ("Rebella", "New Horizon", "Sapporo Autumn Gold", "Rebona" and "Cathedral") part of the affected branches recovered in the next growing season (Tab. 2).
A similar picture may be drawn from the data for crown dieback after 1 year (Tab. S1 in Appendix 1). The same five cultivars were able to produce new shoots and showed flushing in at least $75 \%$ of the crown. However, complete recovery was not seen in these clones, as part of the affected branches died. Eight weeks after inoculations, Alterra clone " 1241 " expressed less symptoms than many other clones, but one year later its crown dieback did not significantly differ from many other clones. "Columella" showed significantly less crown dieback than many others (Tab. S1 in Appendix 1), and performs similar to "Sapporo Autumn Gold", "Rebella", "Rebona", "Cathedral" and "New Horizon" and some of the Alterra clones ("1043", "1315" and "1322").

Correlations between different parameters A strong Spearman's rank correlation coefficient was found between the percentage of defoliation and disease index assessed after 8 weeks $\left(r_{\mathrm{s}}=0.975, \mathrm{p}<0.001\right)$, indicating that clones with a high score for percentage defoliation in general also had a high score for disease index. Disease index after 8 weeks and crown dieback in the next season were also significantly correlated $\left(r_{\mathrm{s}}=0.847, \mathrm{p}<\right.$ 
0.001). Thus both parameters are good for ranking the level of resistance to $O$. novo-ul$m i$ in individual clones. Also, a weak and positive (though not significant) relationship was found between the mean pre-inoculation diamater of clones (June 2008) and 8-weeks disease index and crown dieback after one year $\left(r_{\mathrm{s}}=0.32, \mathrm{p}>0.05\right.$ and $r_{\mathrm{s}}=0.18, \mathrm{p}>$ 0.10 , respectively).

\section{Discussion}

This inoculation test is one of the few studies that compared a large number of wellknown cultivars for resistance to $O$. novoulmi in a common field experiment. Disease scores from different experiments are difficult to compare because the variation in disease symptoms may be caused by many factors, e.g., age of material tested, isolate of the fungus, inoculation method, tree growth and weather conditions (Mittempergher \& Santini 2004, Sutherland et al. 1997). By combining all available cultivars and clones in one field test many of these factors were excluded. Moreover, to further reduce the amount of variation even more clones were propagated under the same conditions as far as possible, material of the same age was used, and all plants were infected with the same isolate. Although variation in symptom development in field tests might still be large as compared to controlled conditions (Smalley \& Guries 1993), it is assumed that the differences observed in this field test among the inoculated clones are related to their genetic background. Despite the limitations of the study, such as the use of only one isolate and the limited number of plants for some clones, our results clearly revealed large differences in the resistance level between individual cultivars and clones. The ranking of cultivars for their level of resistance to $O$. novo-ulmi confirms, with a few exceptions, earlier evidence from the literature and experience from plantings in the Netherlands, as summarized in Heybroek et al. (2009). The few exceptions are "Regal", "Den Haag" and the U. laevis seedlings. "Den Haag"' and the $U$. laevis seedlings are known as toleran elms in Dutch plantings in practice. In our study, U. laevis seedlings were not resistant to $O$. novo-ulmi; the relatively high field resistance of $U$. laevis is due to other factors such as their unattractiveness to the vector Scolytus beetle (Webber 2000). "Regal" is known as a cultivar with very good resistance in the USA (Guries \& Smalley 1990) or as good as "Lobel" in France (Pinon 2007). Nonetheless, "Regal" significantly underperformed "Lobel" in this study. On the other hand, the superiority of "Sapporo Autumn Gold" over the Dutch cultivars "Lobel", "Plantijn", "Clusius" and "Dodoens", which are known as cultivars with good resistance, is in agreement with earlier tests (Green et al. 1985, Pinon et al. 1998). As- sessment based on 4- or 8-weeks disease symptoms compared to symptoms in the following year gives a slightly different ranking because different patterns of disease development are visible. A large group of cultivars and clones showed the same ranking over the whole period of assessment. Another group of cultivars, namely "Cathedral", "New Horizon", "Rebona", "Rebella" and "Sapporo Autumn Gold", from the University of Wisconsin (USA) breeding program clearly behaved differently. They initially react with relatively high disease index and high levels of defoliation (4-weeks after inoculation). However, these cultivars recovered well later on in the same growing season, showing flushing of dormant secondary buds and hardly exhibiting crown dieback in the following year. The most remarkable recovery was shown by "Rebella". In urban plantings the degree of crown damage in the following year is the principal trait of interest for managers, thus the initial disease response in these five cultivars, especially "Rebella", should be of less concern and they could be considered as highly resistant. As our main objective was to rank cultivars for their resistance to $O$. novo-ulmi instead of assessing their level of resistance in real situations, a severe method of inoculation was chosen. The advantage of the Dutch method (wherein a high-dose inoculum is directly brought into the xylem of the lower part of the trunk) is that it leads to strong symptoms, thereby giving conservative estimates for the level of resistance. This also means that, in practice, when these clones are infected in a natural way, they are likely to show even less symptoms than in this test. Consequently, this study has shown that in the present-day assortment there are many cultivars with a good or very good (i.e., better than the reference clone "Lobel") level of resistance.

Resistance to DED is under control of many genes and can be accumulated through subsequent crossings and back crossings. This study suggests that the general level of resistance of released cultivars has increased over time. Comparison of the crown dieback index with the date of release of the cultivars shows a moderate negative correlation $\left(r_{\mathrm{s}}=\right.$ $-0.71, p<0.005)$, suggesting that cultivars released lately have indeed a higher level of resistance. Whether this trend is due to the incorporation and/or accumulation of resistance genes from the Asian germplasm through the production of more complex hybrids, is difficult to say. For instance, the Dutch breeding program initially focused on crossing native European species (U. glabra and $U$. minor) and their hybrids $(U . \times$ hollandica), and the first releases were firstgeneration hybrids or backcrosses between these species ("Groeneveld" and "Commelin"). Lately, advanced generations of hy- brids were produced including Asian germplasm. This next generation of released hybrids (namely "Clusius", "Lobel", "Dodoens" and "Plantijn") all have an U. wallichiana grandparent (1/4). Also the latest cultivar of the Dutch breeding program, the highly resistant "Columella", is an offspring from "Plantijn" and a next-generation hybrid with $50 \%$ U. minor, $25 \%$ U. glabra and $25 \%$ U. wallichiana parentage (Heybroek 1993). Furthermore, "Urban", "Regal" and "Homestead" cultivars are complex hybrids obtained by crossing U. glabra and U. minor in combination with $U$. pumila as a source of resistance. However, these hybrids have varying success for DED-resistance. As a consequence, it may be hypothesized that the improved resistance showed by the newly released cultivars could be due to the enhanced use of Asian germplasm in the recent decades. We see that the most recently released cultivars are mainly F1 hybrids between Asian species, namely the American cultivars "Rebona", "Cathedral", "New Horizon" and "Rebella", which have been released since the nineties and have a comparable level of resistance as "Columella". All are products of crossings between U. pumila and $U$. davidiana var. japonica or U. americana and $U$. parvifolia. Of the 18 elm cultivars tested in this study, eight have $U$. pumila parentage varying from $1 / 4$ to $5 / 8$. In these cultivars U. pumila is used as a source of resistance genes, although from different accessions or provenances. Our results revealed a substantial difference in resistance to O. novo-ulmi among the above cultivars.

Variation in DED-resistance is large within most Asian species (Smalley \& Guries 1993). This study confirms that the use of $U$. pumila not necessarily lead to highly resistant cultivars, depending on the accession used as a source of resistance. Also the nonreleased Alterra selections included in this test are almost all complex hybrids obtained from crossings between native and Asian species (mainly U. wallichiana - Tab. 1). One out of this group (clone "1304") has a parentage with only $U$. glabra and U. minor, demonstrating that it is possible to improve disease resistance by making complex hybrids of purely native European elms.

\section{Conclusion}

The Dutch and American cultivars tested in this study show a large variation in resistance to O. novo-ulmi. In general, their level of resistance corresponds well with the results from breeding trials, other inoculation tests and experiences from plantings in urban green. Furthermore, a considerable number of cultivars with good to excellent resistance to $O$. novo-ulmi are available from the Dutch nursery market. This provides good opportunities for the use of elms as street tree in the future. The widely varying genetic back- 
ground of these cultivars is a positive aspect concerning the stability of the observed resistance against $O$. novo-ulmi in the case new forms of the disease appear. Additionally, several of the unnamed Alterra clones performed well as for resistance compared to the currently available cultivars in the tree nursery market. Such clones have been under evaluation in adaptation trials over the past two decades. Some of these clones have nice architectural characteristics and may be released in the future to further broaden the current range of cultivars for the Dutch and European market.

\section{Acknowledgments}

This study was funded by the Dutch Product Board of Horticulture. Plant material was kindly provided by tree nursery "Bonte Hoek Kwekerijen B.V.". We thank Ronnie Nijboer for arranging this. Thanks are also due to Bram Versprille (Stichting Vermeerderingstuinen Nederland) for providing part of the propagation material and to Gerrit Schalk for assistance in the propagation of some cultivars. We thank Toon Helmink and Jan van Leijden for their technical assistance in performing the inoculation trial and Jacco Alblas for technical assistance in maintaining the experiment. Finally, we want to thank Sven de Vries for his comments on an earlier version of the manuscript.

\section{References}

Geurts P, Hiemstra JA (2002). Zomereik populairste boom voor stedelijk gebied [Pedunculate oak most popular tree for urban green]. Tuin \& Landschap 4: 36-37. [in Dutch]

Green CE, Guries RP, Smalley EB (1985). Early screening of elms for resistance to Ceratocystis ulmi. Plant Disease 69: 60-63. - doi: 10.1094/ PD-69-60

Guries RP, Smalley EB (1990). Selecting and testing elms: the Wisconsin elm breeding program. In: Proceedings of the " $7^{\text {th }}$ Conference of the Metropolitan Tree Improvement Alliance - METRIA 7: Trees for the Nineties". The Morton Arboretum, Lisle (Illinois, USA) 11-12 June 1990, pp. 21.
Heybroek H (1993). The Dutch elm breeding program. In: "Dutch elm disease research: Cellular and molecular approaches" (Sticklen MB, Sherald JL eds). Springer Verlag, New York, USA, pp. 16-25.

Heybroek HM, Goudszwaard L, Kaljee H (2009). Iep of Olm, Karakterboom van de lage landen [Elm, tree with character of the Low Countries]. KNNV Uitgeverij Zeist, pp. 272. [in Dutch] Hiemstra JA, Buiteveld J, Kopinga J, Kranenborg KG, Ravesloot MBM, van der Sluis BJ, de Vries SMG (2006). Belang en toekomst van de iep [Importance and future of the elm]. PPO-Bomen, Lisse, The Netherlands, pp. 50. [in Dutch]

Manly BFJ (2007). Randomization, bootstrap and Monte Carlo methods in Biology. Chapman and Hall/CRC, London, UK, pp. 455.

Martin J, Solla A, Venturas M, Collada C, Dominguez J, Fuentes $\mathrm{P}$, Iglesias S, Gil L (2014). Seven Ulmus minor clones tolerant to Ophiostoma novo-ulmi registered as forest reproductive material in Spain. iForest (early view): e1-e7. - doi: 10.3832/ifor1224-008

Mittempergher L, Santini A (2004). The history of elm breeding. Investigación Agraria Sistemas y Recursos Forestales 13: 161-177. [online] URL: http://www.inia.es/gcontrec/pub/161-177-(14)the_history_1161943529015.pdf

Pinon J (2007). Les ormes résistants à la graphiose [Elms resistant to Dutch elm disease]. Forêt-entreprise 175: 37-41.

Pinon J, Lohou C, Cadic A (1998). Hybrid elms (Ulmus spp.): adaptability in Paris and behaviour towards Dutch elm disease (Ophiostoma novoulmi). Acta Horticulturae 496: 107-114.

Pinon J, Husson C, Collin E (2005). Susceptibility of native French elm clones to Ophiostoma novo-ulmi. Annals of Forest Science 62 (7): 689696. - doi: 10.1051/forest:2005066

Santini A, Fagnani A, Ferrini F, Mittempergher L (2002). San Zanobi and Plinio elm trees. Hortscience 37:1139-1141.

Santini A, Fagnani A, Ferrini F, Ghelardini L, Mittempergher L (2005). Variation among Italian and French elm clones in their response to Ophiostoma novo-ulmi inoculation. Forest $\mathrm{Pa}$ thology 35 (3): 183-193. - doi: 10.1111/j.14390329.2005.00401.x

Santini A, Fagnani A, Ferrini F, Ghelardini L,
Mittempergher L (2007). "Fiorente" and "Arno" elm trees. Hortscience 42 (3): 712-714. [online] URL: http://hortsci.ashspublications.org/content/ 42/3/712.abstract

Santini A, Pecori F, Pepori A, Brookes A (2012). "Morfeo" elm: a new cultivar resistant to Dutch elm disease. Forest Pathology 42 (2): 171-176. doi: 10.1111/j.1439-0329.2011.00737.x

Smalley EB, Guries RP (1993). Breeding elms for resistance to Dutch elm disease. Annual Review of Phytopathology 31: 325-352. - doi: 10.1146/ annurev.py.31.090193.001545

Solla A, Martín JA, Ouellette G, Gil L (2005). Influence of plant age on symptom development in Ulmus minor following inoculation by Ophiostoma novo-ulmi. Plant Disease 89 (10): 1035 1040. - doi: 10.1094/PD-89-1035

Sutherland ML, Mittempergher L, Brasier CM (1995). Control of Dutch elm disease by induced host resistance. Forest Pathology 25 (6-7): $307-$ 315. - doi: 10.1111/j.1439-0329.1995.tb01346.x Sutherland ML, Pearson S, Brasier CM (1997). The influence of temperature and light on defoliation levels of elm by Dutch elm disease. Phytopathology 87: 576-581. - doi: 10.1094/ PHYTO.1997.87.6.576

Tchernoff V (1965). Methods for screening and for the rapid selection of elms for resistance to Dutch elm disease. Acta Botanica Neerlandica 14 (4): 409-452. - doi: 10.1111/j.1438-8677.19 65.tb00204.x

Webber JF (2000). Insect vector behavior and the evolution of Dutch elm disease. In: "The elms: breeding, conservation and disease management" (CP Dunn ed). Kluwer Academic Publishers, Boston, USA, pp. 47-60.

\section{Supplementary Material}

Appendix 1 - Differences between clones in average disease index 4 weeks, 8 weeks and average crown dieback one year after inoculation (average of 3 inoculations). Values with the same letter do not differ significantly $(\mathrm{p}<0.05)$.

Link: Buiteveld_1209@supp1001.pdf 